\title{
HATE CRIME - CRIMINOLOGICAL AND LEGAL ASPECTS
}

\author{
Darko Dimovski \\ Associate Professor, Faculty of Law, University of Nis, \\ E-mail: darko@prafak.ni.ac.rs \\ MišaVujičić \\ Judge Assistant, Court of Appeals in Nis, \\ E-mail: misa.vujicic@ni.ap.sud.rs \\ Milan Jovanović \\ Trainee of Judge, Commercial Court in Nis, \\ E-mail:milan993@gmail.com
}

\begin{abstract}
In their introduction, the authors have emphasized that even though hate crime has been criminalized in the XX century, it has existed throughout the entire human history. The overview of the first laws regulating hate crime has been laid out in the introduction as well. Special attention has been attached to the theoretical notion of this form of violent crimes. As the dissemination of hate crime is an important phenomenological data, the authors presented the results of the criminological studies on the dissemination of hate crime in the United States of America. Hate crime is not a uniform type of violent crimes, thus it is necessary to review its manifestation and appearances, as the authors sought to in this article. The victims themselves mostly suffer consequences of hate crime, so the next part of the article is focused on the consequences themselves. The final part relates to legal framework on hate, as a mandatory aggravating fact of certain crimes in Republic of Serbia, with overview of crimes that involve hate as element in their legal determination. At the same time, the authors aimed to show the results of the research on the application of the Article 54a of the Serbian Criminal Code in case-law of courts in Nis and Novi Sad.
\end{abstract}

Keywords: hate crime, criminological aspect, legal aspect.

\section{INTRODUCTION}

human history is filled with examples that would fall under the modern term of hate crime. These crimes not only affect the victims themselves, but they even shape the history of some nations. It is sufficient to recall the persecution of the followers of the Christianity by the Romans, crimes towards the Native Americans during the colonization of the continent, crimes against the Armenians by the Ottoman Turks, apartheid in South Africa etc.

\footnotetext{
${ }^{*}$ The work was created as a result of funding from the Ministry of Education, Science and Technological
} Development of the RS according to the contract registration number 451-03-68 / 2020-14 / 200120 
Irrespective of the long history of hate crime, it should be highlighted that only during the 60 's and the 70's of the XX century the first efforts towards its incrimination have been made. Hence, the United States`Congress has adopted the Civil Rights Act in1964, which, for the first time, made the difference between "regular" crimes and the crimes with prejudice in it. Accordingly, it prescribed special prosecution of those who willingly make attack, intimidate or in another way harm a person due to its race, color, religion or ethnicity. At the same time, making lists for voting or for school enlisting on the aforementioned grounds was also banned. Beside the fact that the Act was primarily aimed at human rights improvement, it was the first one to prescribe hate crime. It should be highlighted though, that not all possible manifestations of hate crime were involved. ${ }^{1}$ The very aim of this Act was banning discrimination, which was a basis for developing prejudice, which results in hate crime. In addition, it forbid discrimination by the federal and state bodies on aforementioned grounds when accessing public institutions. Discrimination during the stays at the hotels, motels, restaurants, theaters and other public places was just as equally forbidden by this Act. $^{2}$

In decades to come, American Congress adopted series of laws, i.e. the Civil Rights Restoration Act from 1988, or the Civil Rights Act of 1964, which served as a further guidance point for new incriminations of hate crime. In spite of active legislative, during the 80 's there was a spike in activities of groups based on racism, hatred and prejudice towards other. Hence, under the influence of NGO's, such as the Southern Poverty Law Center (SPLC) or the Anti-Defamation League (ADL), United States` Congress adopted the Hate Crime Statistics Act in 1990. It created an obligation to gather process and publish data on crimes committed on the grounds of prejudice based on race, religion, sexual orientation and ethnicity. Adoption of this Act created a synergy in legislative activities on the state level, which adopted their own laws incriminating hate crime, except for Wyoming, Georgia, Arkansas, South Carolina and Indiana. ${ }^{3}$

\section{THE DEFINITION OF HATE CRIME}

Federal bureau of investigation (FBI) determines hate crime as crime against a person, property or a society, entirely or partially motivated by perpetrator`s prejudice on the grounds of race, religion, disability, sexual orientation, ethnicity or gender. ${ }^{4}$

One of the accepted definitions of hate crime was made by California Attorney General`s Commission on Racial, Ethnic, Religious and Minority Violence. It

\footnotetext{
${ }^{1}$ Retrieved 4 March 2016 from http://prospect.org/article/daily-meme-brief-history-hate-crime

2 Turpin-Petrosino, C. (2015): Understanding Hate Crimes: Acts, Motives, Offenders, Victims, and Justice, Routledge, London, 7.

${ }^{3}$ Turpin-Petrosino, C., op. cit., 10.

${ }^{4}$ Lau Chin, J. (2004): The Psychology of Prejudice and Discrimination: Bias based on gender and sexual orientation, Praeger, London, 163.
} 
describes it as any act of intimidation, harassment, use of physical force or threat issued towards any individual or their family, property or their attorney, when such an act is motivated entirely or partially by hostility towards their real or misinterpreted race, ethnicity, religion, gender, age, disability or sexual orientation, with an aim to intimidate a person or deny them from enjoying a right guaranteed by the Constitution and the laws of the United States of America or the State of California. ${ }^{5}$

In addition, criminologists were trying to define hate crime as well. For example, Boyd and his associates affirm that hate crime is a crime committed against a person or a property, which is based on hatred or prejudice towards racial, ethnical, religious or sexual identity of a victim. Other criminologists, such as Craig, Barnes and Ephross, have broadened this notion by physical disability as one more of the grounds of hatred. Craig and Waldo, on the other hand, highlighted that hate crime relates to any crime motivated by hatred, including words or acts aimed at making injuries or intimidating an individual due to their affiliation with a certain group of people. Such a definition stirred a lot of controversy, as it was presupposed that the attacks of the Whites towards African-Americans are identical to their attacks towards the Whites, thus neglecting the social dominance of the latter in the contemporary society. By looking the aforementioned definition of hate crime, some could conclude that members of homosexual orientation make attacks towards the heterosexual majority, which is rarely the case. Due to these reasons, Craig has adapted his definition of hate crime by stating it is any illegal action with intent of separating a victim on the grounds of prejudice, which relates to victim's real or presupposed status. Status implies affiliation to racial, ethnical, religious, sexual group or group of people with disabilities. Through this definition, Craig included illegal activities aimed at vulnerable social groups. ${ }^{6}$

\section{THE PREVALENCE OF HATE CRIMES}

A survey conducted as part of the National Crime Victimization Survey provided the approximate data on the actual number of hate crimes committed in the United States. According to estimates made in this study, in the period from 2003 to 2009, about 195,000 cases of victimization were committed annually as a consequence of hate crime, including about 179,000 hate crimes against persons over 12 years of age. It should be noted that the higher number of victims than the perpetrators is due to a higher number of victimizations within only one hate crime committed. At the same time, the research showed that $23 \%$ of all hate crime committed include serious violence, and it should be emphasized that during 2009, eight murders were committed with hatred element involved. ${ }^{7}$

\footnotetext{
${ }^{5}$ Jenness, V., Broad, K. (2009): Hate Crimes: New Social Movements and the Politics of Violence, Aldine Transaction, New Jersey, 144.

${ }^{6}$ Perry, B. (2003): Hate and Bias Crime: A Reader, Routledge, New York, 29.

${ }^{7}$ Hall, N. (2013): Hate Crime, Routledge, New York, 130.
} 
This research made it possible to find data and establish the relationship between perpetrators and victims of hate crimes. Thus, in $37 \%$ of the cases, the perpetrator had prior knowledge of the victim, which is less than the percentage of previous knowledge of a victim in crimes where there is no element of hatred - 50\%. Furthermore, one third of the hate crimes were committed in the victim`s home, or near their place of residence, while in other crimes, that percentage is significantly higher and amounts to 50 percent. However, the percentage of hate crimes committed in schools is twice as high as the percentage of other crimes committed there - $18 \%$ versus $9 \%$. Younger people are at higher risk of victimization. Thus, persons between the age of 12 and 24 have more chance ofbecoming victims of hate crime than persons over the age of 50. Men, as well as people who earn less than 25.000 US dollars a year, have a higher chance of being victims of hate crimes than women, or people who earn more than 25.000 USD annually.

The study has also shown that hate crime cases with elements of violence, are most commonly committed between members of different races, while hate crimes without violence more commonly occurs between members of the same race. According to the victims' testimonies, hate speech is used when committing hate crimes. However, it is interesting that only one in ten perpetrators leaves symbols related to the hate crime at the crime scene. Finally, it should be mentioned that $45 \%$ of the hate crime victims are people with a certain disability. ${ }^{8}$

Although the figures obtained by this survey might seem frightening, it is necessary to note that they make up to only $1 \%$ of total number of crimes committed in the USA. However, one should be especially careful in making a final conclusion on whether hate crime poses a serious threat to the overall security of citizens in the United States, because four out of five hate crimes committedinvolve violence.

A more recent study, also conducted as part of a victimization survey, showed interesting results. The research included the period from 2007 to 2011. It was estimated that there were 259,700 people by over the age of 12 years and residing in the United States being victimizedannuallyin the context of non-lethal and the property hate crime. If we compare the annual number of hate crime victims in the period from 2003 to 2006 and from 2007 to 2011, we can see that the number of lethal hate crimesis equal in both periods. Hate crimes committed because of some religious prejudices have the largest increase in the given period. In the first given period from 2003 to 2006 year -there was $10 \%$ of hate crimes based on religious bias, while in the next period from 2007 to 2011 , the percentage has more than doubled - $21 \%$. Unlike the religiously biased hate crime, racially induced hate crime is on a slight decline. In the first period, it amounted to $63 \%$ of hate crimes, while in the second period, that percentage was $54 \%$. The degree of social danger of hate crimes is shown by the $92 \%$ of the hate crime cases were committed with elements of violence. ${ }^{9}$

\footnotetext{
${ }^{8}$ Hall, N., op. cit., 130-131.

${ }^{9}$ Hall, N., op. cit., 131-132.
} 
At the same time, in the second period, special attention is drawn to certain victimological data. For example, data were collected in the area where these forms of violent crime were committed, where it was established that one third of hate crimes were committed at home, or near the victims' place of residence. As the data regarding the risk of victimization of members of certain races are very important, criminologists dealt with these facts when processing the obtained data. The obtained results showed that members of the white race, black race, as well as Hispanics, have the same percentage of victimization of violent hate crimes. ${ }^{10}$

\section{FORMS OF HATE CRIME}

Different typologies of hate crime can be found in criminological theory. The criminologists Levin and McDevitt highlighted in 1993 the existence of four forms of hate crime: thrill-seeking hate crime, defensive hate crime, mission hate crime and retaliation hate crime. ${ }^{11}$

Most crimes that fall within the thrill-seeking hate crime can be classified as vandalism, physical attacks, as well as intimidation. The object of the attack are not only individuals, but also property. At the same time, in the case of physical attacks, it is possible, although not so often, to have lethal consequences. Perpetrators of the thrill-seeking hate crime look at their behavior as a kind of game in which they seek to establish domination over the victim, alongside with some thrill and excitement for the perpetrator. ${ }^{12}$ Teenagers that assemble during the weekends after playing cards, choosing to destroy the property of certain individual or to intimidate members of some minority group, are mentioned as an example of this form of hate crime. According to a Boston police report, three out of five hate crimes were committed out of excitement. Furthermore, $53 \%$ of all the thrill-seeking hate crimes were committed by two or more teenagers, who attacked the victims in their area seeking excitement. According to this report, the majority of perpetrators of the thrill-seeking hate crime are white minors, where even $91 \%$ of them didn't know the victim prior to the incident. In $70 \%$ of the thrill-seeking hate crime, there is a physical attack involved, although we have pointed out that this form of hate crime can also be reflected in vandalism or intimidation. ${ }^{13}$

With this form of hate crime, individuals become victims by accident. In addition, the victims are members of minority groups that the perpetrator sees as inferior to

\footnotetext{
${ }^{10}$ Hall, N., op. cit., 132.

${ }^{11}$ Krohn, M., Lizotte, A., Hall, G. P. (2009): Handbook on Crime and Deviance, Springer, London, 539.

12 Momen, R. (2008): Empirical Study of Hate Crimes in the United States: A Systematic Test of Levin and McDevitt's Typology of Offenders, ProQuest, Morgantown, 9.

${ }^{13}$ Kurtz, L. (1999): Encyclopedia of Violence, Peace, and Conflict, Three-Volume Set, Academic Press, San Diego, 94.
} 
himself. The reason for the existence of dominance and inferiority can be found in the general atmosphere in society that exists towards the members of that minority group. This atmosphere may result in the attitude that no one will care whether members of a minority group are exposed to victimization or not. Members of homosexual or bisexual groups generally appear as victims of thrill-seeking hate crime, while the perpetrators are usually couples or smaller groups. Already mentioned criminologists Levin and McDevitt pointed out that homosexuals are "ideal" victims of this form of hate crime for several reasons. Namely, homosexuals gather in certain parts of the city, which makes it easier for potential perpetrators to find them. At the same time, according to the perceptions of members of the dominant group, the existence of a group of homosexuals can pose a threat to the development of sexual identification of teenagers. The last reason why homosexuals make ideal victims of thrill-seeking hate crime is their unwillingness to report the attacks they are exposed to, because they find themselves in a situation to reveal their sexual orientation not only to the wider local community, but also to their family members. In other words, by reporting hate crimes, they would be exposed to secondary victimization. ${ }^{14}$

The struggle to reduce the volume of thrill-seeking hate crime should be reflected in the application of strict sanctions against the perpetrators, because such crimes are not motivated by greed. Eventual impunity for such socially unacceptable behaviors will only encourage the thrill-seeking hate crime, which can, as already pointed out, result in a fatal outcome. ${ }^{15}$

The next form of hate crime is known as defensive hate crime. Until 2002, the creators of this typology used a different name for this form of hate crime - reactive hate crime. However, careful analysis of the motives for committing this form of hate crime changed its name to defensive hate crime. Namely, the defensive hate crime does not seem to be committed for the sake of excitement, but as a means by which the accumulated aggression is manifested. The perpetrators of this crime experience attacking as taking defensive measures to protect not only themselves, but also the local community. The difference between these two mentioned forms of hate crime is also reflected in the age of the perpetrators. While the thrill-seeking hate crime is usually committed by teenagers, defensive hate crime is mostly committed by the adults. Another distinction with thrill-seeking hate crime is that the perpetrators do not go to the place where the victims live or gather, but they commit crimes in their own areas of work or residence. ${ }^{16}$

In the case of thrill-seeking hate crime, any member of a certain group can be victimized, while in the case of defensive hate crime, there is a tendency for perpetrators to always target an individual or a small group of individuals who they

\footnotetext{
${ }^{14}$ Momen, R. op. cit., 9-10.

15 Ibid.

${ }^{16}$ Ibid.
} 
consider a threat to personal safety or safety of their families. Examples include the African-Americans settling in a neighborhood generally inhabited by white people. Moreover, crime does not have to be preceded by aggressive behavior of the perpetrator or the commission of other criminal acts. The motive for committing a defensive hate crime may be a concern about possible theft (for example in the event of an African-American family settling to an exclusively white area). ${ }^{17}$

A study under the Klanwatch project in the state of Alabama showed that almost half of the racially motivated acts of vandalism and violence were directly related to the relocation of African-Americans to a white-dominated neighborhood. ${ }^{18}$ The most striking example of the defensive hate crimes in this study is the killing of Purnell Daniels, a 41-year-old African-American engineer who resides in Newark, Delaware, dominantly white neighborhood. He found a threatening letter written by members of the $\mathrm{Ku}$ KluxKlan at the door of his house. Another good example for illustrating defensive hate crime is the incident that occurred in 1997. A group of whites in Gryson, Georgia, shouted racial slurs at a young African-American couple who was transferring their belongings to a house in a white neighborhood. When a group of white people realized that the married couple did not intend to move out, but to stay, several shots were fired at the house where the married couple was at the time of the shooting. Seeing that the group of whites was serious in their intention not to allow them to live in this area, a couple of African-Americans seriously considered the option of moving out of Gryson. ${ }^{19}$

Another study, conducted by criminologists John Weiss, Howard Ehrlich and Barbara Larcom, taken on a sample of 2,078 Americans found that $27 \%$ of them reported some form of hate crime at work. ${ }^{20}$

The next form of hate crime is mission hate crimes. Although this form of hate crime is rarely committed, it should be noted that it is considered the most heinous, because in its essence there is a mission to eliminate persons who are considered less valuable than other people. Perpetrators of the mission hate crimes have a moral and religious obligation to destroy a certain group of people before that group comes into a position to destroy them. ${ }^{21}$

The existence of such an "obligation" results in bodily harm or even murder. To illustrate the prejudice in this form of hate crime, perpetrators often believe, for example, that Jews are children of the devil, African-Americans and Hispanics are dirty people, people with intellectual disabilities are retards, and that members of sexual

\footnotetext{
${ }^{17}$ Kurtz, L., op. cit., 95.

${ }^{18}$ Levin, J., McDevitt, J. (2002): Hate crimes revisited: America's war against those who are different, Basic book, New York, 80.

${ }^{19}$ Kurtz, L., loc. cit.

20 Ibid.

${ }^{21}$ Krohn, M., Lizotte, A., Hall, G. P., loc. cit.
} 
minorities are deviant. Such prejudices inevitably lead to the commission of crimes with serious consequences for the integrity of these persons. Multiple manifestations of aggression towards certain individuals can be monitored in individuals instilled with such hatred, since they become members of organized so-called "hate groups", sometimes undergoing training in the use of fire. ${ }^{22}$

As an example of this form of hate crime, we can cite a case that happened relatively recently. In August 2012, a 41 -year-old man named Wade Michael Page killed six members of a Sikh Indian temple in Oak Creek, Wisconsin, after which he committed suicide. His hatred can be traced back to 2000, when he became a member of several neo-Nazi groups, among which End Apathy and Definite Hate stand out. At neo-Nazi meetings, he often talked about the upcoming "holy war" against members of other races. Another detail shows the degree of hatred of Michael Page towards minority groups. Paige made multiple tattoos on his body on the supremacy of the white race in relation to members of other races. ${ }^{23}$

The last form of hate crime, according to the typology of criminologists Levin and McDevitt, is retaliation hate crimes. The commission of a retaliation hate crime occurs when the perpetrator believes that there has previously been an attack by another person on an individual who is a member of the same group as the perpetrator. ${ }^{24} \mathrm{~A}$ vengeful hate crime can be committed not only when there is a previous violent incident, but also when there is some gossip. Therefore, due to the existence of some rumors, a certain group may take an act of revenge against those who spread those rumors. ${ }^{25}$ Other criminologists have stressed that retaliation hate crimes can occur even when the victim lost confidence in the police and judicial authorities, and take justice into their own hands and carry out violent criminal act according to their abuser. According to criminologists, the existence of domestic violence can be conditioned by the so-called a vengeful crime of hatred towards the perpetrator, whereby there is a change of position in the relationship between the perpetrator and the victim. ${ }^{26}$

The motive of revenge is responsible as well for the escalation of violence between members of different groups. It suffices to mention the increase in the level of violence between Catholics and Protestants in Northern Ireland. Thus, any attack on members of one religious group triggers the revenge of the members of the attacked religious group on the attackers, which created a loop of mutual revenge attacks. ${ }^{27}$

22 Iganski, P., Levin, J. (2015): Hate Crime: A Global Perspective, Routledge, New York, 49.

${ }^{23}$ Ibid.

24 Turpin-Petrosino, C., op. cit., 86,

${ }^{25}$ Perry, B., op. cit., 112.

${ }^{26}$ Hall, N., Corb, A., Giannasi, P., Grieve, J. (2015): The Routledge International Handbook on Hate Crime, Routledge, London, 370.

27 Roulstone, A., Mason-Bish, H. (2013): Disability, Hate Crime and Violence, Routledge, London, 101. 
At the same time, it should be emphasized that revenge, as a motive for committing hate crime, also exists in attacks involving persons with disabilities. On January 19, 2007, 16-year-old John Odgren stabbed to death a 15-year-old student, in a toilette of Lincoln-Sudbury High School in Massachusetts. The killer suffered from Asperger's syndrome, depression and obsessive-compulsive disorder, because of which he was a victim of abuse by his schoolmates for many years. After some time, he decided to take revenge for his victimization. ${ }^{28}$ Therefore, he brought a knife to school, killing an accidental victim - a person he had never met before. Odgren was fascinated with Stephen King's books, repeatedly pointing out that his plan was to commit a perfect crime. He also developed an irrational fear that something bad is to happen to him. ${ }^{29}$

It is necessary to emphasize that Odgren had a long history of aggressive behavior. Even though still in the third grade, he threatened the girl was abusing him that he will kill her with the use of firearms. The following year, he stuck a ballpoint pen in the chest of his fellow student. He displayed his aggressive behavior in each of the schools he was transferred to. ${ }^{30}$

In addition to the aforementioned division of hate crime, there are criminologists whopointed out the existence of other forms of hate crimes while studying crimes committed out of hatred towards homosexuals. Criminologists like Herek distinguished three forms of hate crime: experimental hate crime, symbolic hate crime and defensive hate crime. Herek later emphasized that this typology of hate crime can be extended to all victims of hate crime, not only to homosexual victims. ${ }^{31}$

In experimentalhate crime, there is a representation of reality based on previous experience with members of the homosexual community. There are members of the predominantly heterosexual community who, based on their previous experience, have a good opinion of homosexuals. However, some other heterosexuals have a negative attitude towards homosexuals solely because of a negative experience with them in a previous period of their lives, which can generate this form of hate crime. Without prior experience with homosexuals, members of sexual minorities are seen by heterosexuals more as symbols of enjoying complete freedom in choosing a sexual partner, rather than as persons of flesh and blood. ${ }^{32}$

The next form of hate crime according to Herek is a symbolic hate crime. In this form of hate crime, there is a prejudice that manifests itself in such a way that

\footnotetext{
${ }^{28} \mathrm{Ibid}$.

${ }^{29}$ Lebrun, M. (2012): Rebels in Society: The Perils of Adolescence, Rowman \& Littlefield Publishers, Lanham, 122.

${ }^{30}$ Roulstone, A., Mason-Bish, H., op. cit., 101-102.

${ }^{31}$ Hall, N., Corb, A., Giannasi, P., Grieve, J., op. cit., 393.

32 Retrieved 21 March 2016 from: http://psc.dss.ucdavis.edu/rainbow/HTML/prej_func.html
} 
the perpetrator identifies himself with other persons who express hatred towards individuals (homosexuals). There is solidarity among certain individuals with the aim of further exclusion of their victims from social life (Hall et al, 2015: 393). ${ }^{33}$ The attack on individual homosexual sends a strong message to other members of the homosexual community that they are not welcome. When we talk about the symbolic hate crime in which the victims were not just homosexuals, we can cite cases where they send messages to Americans of Asian origin that they cannot consider themselves Americans, as well as that they do not belong there ${ }^{34} \mathrm{As}$ the defensive hate crime according to Herek's typology has already been examined, we shall not explain it further.

\section{CONSEQUENCES OF HATE CRIMES}

Criminal activities result in numerous mental and emotional difficulties on persons who are victims of this socially unacceptable behavior. However, it should be emphasized that these consequences are especially manifested within the hate crime victims. The realization of this fact has contributed to the development of numerous programs to help hate crime victims. It is preceded by numerous criminological studies, which were conducted with aim to determine the type and extent of consequences suffered by the victims of this form of violent crime. The carriers of these criminological studies during the 1990s were Barnes, Ephross, Hershberger, D’Aguelli, Otis and Skinner.

Although pioneering research showed a number of consequences for victims of hate crime, they were at the same time limited, since they weren't compared to consequences of other crimes committed. It was therefore necessary to make additional efforts to establish whether the hate crime resulted in the same consequences as other criminal offenses or whether those consequences were even greater in scale. Subsequent research was conducted on a small number of samples, which provided additional quality. For example, criminologist Herekand his associates, who were already mentioned, conducted a research in 1999, measuring the consequences of hate crime against persons of homosexual orientation, and comparing them with the consequences for various other crimes. Study has shown that victims of hate crimes feel a higher degree of depression, traumatic stress and anger compared to victims of other criminal behaviors. ${ }^{35}$

Next criminological study on victimological aspect of hate crime was done by mail in 2001 in Boston, and was conducted by criminologist McDevitt, whom we have already mentioned, alongside his associates. Namely, this research created two groups - an experimental group consisting of victims of hate crimes and a control

\footnotetext{
${ }^{33}$ Hall, N., Corb, A., Giannasi, P., Grieve, J., loc. cit.

34 Perry, B. (2009): Hate Crimes, Greenwood Publishing Group, London, 119.

35 Chakraborti, N., Garland, J. (2015): Responding to Hate Crime: The Case for Connecting Policy and Research, Policy Press, Bristol, 232.
} 
group composed of victims of various other crimes. The results of the research showed a significant difference in terms of psychological consequences - victims of hate crimes suffered psychological consequences to a much greater extent, reflected in increased depression, nervousness, lack of concentration, preoccupation with their thoughts about the unpleasant event as well as self-blame. However, certain shortcomings of this research should be noted, primarilya small number of people who were willing to participate in the criminological study. ${ }^{36}$

The problem of insufficient number of people was eliminated by further research, which collected the data in the territory of England and Wales during the period 20092011. The research showed that the victims of hate crimes, unlike the victims of other crimes, suffer largely from feelings of shock, fear, depression, anxiety, panic attacks, loss of self-confidence and feelings of vulnerability. ${ }^{37}$

At the same time, it is necessary to emphasize that the hate crime does not only affect and produce consequences upon direct victims. Hate crime produces fear for one's own safety even in persons who have the same characteristics as victims of hate crimes committed, which increases their risk of victimization. ${ }^{38}$ Based on this fact, public authorities are obliged not only to respond in a timely manner with regard to the detection and prosecution of hate crime against direct victims, but also in order to prevent the spread of fear and unrest among persons belonging to the same group as the direct victim.

\section{HATE CRIME IN THE CRIMINAL LAW OF THE REPUBLIC OF SERBIA}

Revision of the Criminal Code in 2012 added the Article 54a to the Serbian Criminal Code, which foresees a special circumstance when sentencing for a criminal offense committed out of hatred. Article 54a stipulates that if the criminal offense was committed out of hatred due to race, religion, national or ethnic affiliation, gender, sexual orientation or gender identity of another person, the court will assess this circumstance as an aggravating circumstance, unless it is explicitly prescribed as a feature of the crime.

By careful analysis of the legal text, we can see that Article 54 of the Criminal Code prescribes general rules on sentencing, emphasizing that the motive will be taken into account when sentencing. In that way, the hate element could be taken as a motive for criminal behavior. However, the legislator was of the opinion that by specially prescribing hatred as an aggravating circumstance, it would raise criminal protection of particularly vulnerable social groups to a higher level, since their members have been victimized solely due to belonging to these social groups. ${ }^{39} \mathrm{However}$, it should ${ }^{36}$ Phillips, C., Webster, C. (2013): New Directions in Race, Ethnicity and Crime, Routledge, London, 30. ${ }^{37}$ Ibid.

${ }^{38}$ Mizrahi, T., Davis, L. (2008): The Encyclopedia of Social Work: 4 Volume Set, Oxford University Press, Oxford, 315.

39 Miladinović, J. (2015):Procesuiranje zločina iz mržnje: mržnja kao obavezna otežavajuća okolnost, 
be emphasized that the legislator should not have used exhaustive enumeration of the grounds for the existence of hatred, without detailing its grounds for hatred in sufficient detail. The question justifiably arises as to whether this provision could be applied if the hatred was directed towards persons with certain mental or physical disabilities. By linguistic interpretation of provision 54a of the Criminal Code, we come to the conclusion that there is no place for the application of more severe punishment if the criminal offense is committed out of hatred towards persons with disabilities. However, even in such cases, it is possible, without changing the provision $54 \mathrm{a}$ of the $\mathrm{CC}$, to strengthen the criminal law protection, of persons with disabilities solely by applying the general provisions on sentencing. In order to overcome this shortcoming, besides listing the specific characteristics that are protected by law, the legislator should leave an opportunity for some other characteristics to appear as a basis for qualifying a certain act as to impose a heavier penalty. Another option is for the legislator to expand the grounds of hatred, as it has been done in Article 2 of the Law on Prohibition of Discrimination. ${ }^{40}$

It should be emphasized that even prior to Revision of the Criminal Code in 2012, when it launched a hatred as a special aggravating circumstance, domestic legislator was sufficiently sensitive to criminalize specific offenses that are committed due to hatred as motives. Back in 1986, an amendment to the Criminal Code of the Socialist Republic of Serbia was made, which introduced criminal acts of "violence that endangers the freedoms and rights of citizens, members of other peoples, nationalities or ethnic groups" (Article 61a), "special forms of endangering freedoms and the rights of citizens of other peoples, nationalities or ethnic groups "(Article 616), as well as criminal offenses entitled "endangering the security of citizens of other peoples, nationalities or ethnic groups by attacking sexual freedom"(Article 61c). The reason for such criminalization should be sought in the case that shocked the public of the former SFRY at that time. On May $1^{\text {st }} 1985$, Djordje Martinovic was attacked in a field near Gjilan (Kosovo and Metohija). The attack was carried out by charging a stake, with a half-liter glass beer bottle on top of the stake. The victim reported that it was done by ethnic Albanians. Aforementioned offenses were decriminalized only couple of years later, through the amendment of criminal legislation in $1994 .{ }^{41}$

According to the analysis of the existing Criminal Code, there are criminal acts which involve hatred as their element - "inciting national, racial and religious hatred and intolerance"(Article 317) within the chapter "Criminal offenses against the constitutional order and security of the Republic of Serbia". This crime forbids acts aimed to provoke or incite national, racial or religious hatred, or intolerance among the peoples or ethnic communities living in Serbia. In addition to the basic

Bilten sudske prakse, Niš, 37.

${ }^{40}$ Law on Prohibition of Discrimination, „Official Gazette RS“, No.22/2009;

${ }^{41}$ Miladinović, J., op. cit., 51. 
form, there are two aggravated forms. At the same time, one of the aggravated forms of murder - murder out of reckless revenge or other low motives, is such a form of aggravated murder which, according to the judgment of the Supreme Court of Serbia (Kž 2015/57), is committed for motives that are not worthy of a man. Namely, the Supreme Court took the position that low motives are motives that are not worthy of moral understandings in society, which leads us to the conclusion that such motives include hatred, envy, malice, intolerance and others. In other words, hate murder can be classified as murdercommitted out of other low motives.

In addition to the already analyzed hate-driven crimes, there are some other criminal acts based on hatred - violent behavior at a sports event or public gathering (Article 344a), as well racial and other discrimination (Article 387). Primarily, it was Article 20 of the Law on Prevention of Violence and Misconduct at Sports Events ${ }^{42}$ that incriminated violent behavior at a sports event. This crime was latter in 2009 transferred into the Criminal Code (Article 344a). By doing so, the legislator only slightly changed the elements of this crime. After only 4 months, this criminal act was significantly modified through the amendments to the Criminal Code, whereby the name was changed to "violent behavior at a sports event or public gathering".

Specifically, the act of a criminal offense is determined alternatively, whereby the criminal offense can be committed by any person. The legislator prescribed that the criminal act should take place at a sports event or public gathering, as well as the consequences of such an act. The criminal offense consists in the alternative performance of numerous actions. Bearing in mind that the subject of our analysis is hate crime, we shall pay special attention only to one form which integrates hatred as its integral element. The violent behavior at sports events or public gatherings may be, inter alia, executed by causing national, racial, religious or other hatred or intolerance based on discriminatory grounds, through their own behavior or through slogans at a sports event or public meeting, due to which there is a violence or physical confrontation with its participants. The consequence is endangering people and property of greater value. Endangerment should be specific, with immediate, close and real danger. The basic form of this criminal offense is punishable by imprisonment from 6 months to 5 years and a fine. If the act was committed by a group, a prison sentence of one to 8 years is prescribed, while the ringleader of the group can be sentenced from 3 to 12 years in prison. For the perpetrator of this criminal act, it is predicted to impose a security measure prohibiting him from attending certain sports events in the future.

As it has already been emphasized, The Criminal Code of the Republic of Serbia incriminates another criminal offense in whose essence is hatred as an integral element. Within Chapter XXXIV of the Criminal Code, there is a criminal offense of racial and other discrimination (Article 387). This criminalization occurred due to Convention

\footnotetext{
${ }^{42}$ Law on Prevention of Violence and Misconduct at Sports Events, „Official Gazette RS“, No. 67/2003, 101/2005, 90/2007, 72/2009, 111/2009 and 104/2013;
} 
on the Elimination of All Forms of Racial Discrimination of 1965, the International Convention on the Suppression and Punishment of theCrime of Apartheid of 1973, as well as Article 14 of the European Convention on Human Rights. Actus reus in the basic forms of both of these crimes consists in violation of basic human rights and freedoms guaranteed by generally accepted rules of international law and ratified international treaties by the Republic of Serbia, resulting is discrimination on the grounds of race, color, religion, nationality, ethnic origin or some other personal characteristic. In addition, the legislator also incriminated special forms of this criminal offense (Article 387, paragraphs 3, 4 and 5).

In addition to thesehatred-based criminal offenses, Serbian legislator, as we have already mentioned, prescribed hatred as an obligatory aggravating circumstance for any other criminal offence. Since 2012, the possibility of using hatred as an obligatory aggravating circumstance has been prescribed, the authors of the article conducted research in the Municipal and High Courts in Nis, as well as in the Municipal and High Courts in Novi Sad, in order to determine the number of judgements where Article 54a of the Criminal Code is applied. The results showed no cases where this provision on hate as mandatory aggravating circumstances is applied. With these results, we can conclude that judges in hate crime cases do not find it appropriate to apply provision of Article 54a of the $\mathrm{CC}$, because they have not received adequate training on the purpose and scope of hatred as mandatory aggravating circumstances. Therefore, it is necessary to organize seminars from the experts with examples of hate crime, where this provision could be applicable.

\section{SUMMARY}

Over the past century, many countries have introducedhate crimes into their legislation as a separate criminal offense or as mandatory aggravating circumstances prescribed in the general criminal law or only regarding certain criminal offenses. Following the tendencies in the leading countries of criminal law, the Republic of Serbia incriminated the motive of hatred as a particularly aggravating circumstance when sentencing a defendant and determining the punishment.

However, it is worrying that several years have passed since the introduction of such a legal solution in Serbian criminal legislation, while the judges have not been able to recognize cases where it is possible to apply provision of Article 54a of the Criminal Code in hate crime cases, since those cases undoubtedly happened. The reason for that may lie in the fact that practitioners do not know what does the hate crime imply, because the legislator failed to further explain it in the part related to the meaning of expressions used in the incrimination of certain acts. In order to overcome all the uncertainties regarding hate crime, it is necessary that the Criminal Code proscribe what does the term hate imply, as previously pointed out. In addition, it should leave open list of characteristics of individuals that form the basis of hate or rather use solution of Article 2 of the Law on Prohibition of Discrimination. 
At the same time, it is necessary to work on educating not only judges, but also other subjects in the fight against crimein the upcoming period, in order to highlight that hate crime requires a stricter reaction of the state in terms of sentencing. Therefore, special attention should be drawn to the training of personnel of internal affairs, because they should be the first to recognize a motive of hatred. The state's response to hate crime would be much more productive if the internal affairs authorities had a unified system for processing criminal data with elements of hatred.

\section{LITERATURE}

1. Chakraborti, N., Garland, J. (2015): Responding to Hate Crime: The Case for Connecting Policy and Research, Policy Press, Bristol, 232.

2. Hall, N. (2013): Hate Crime, Routledge, New York, 130.

3. Hall, N., Corb, A., Giannasi, P., Grieve, J. (2015): The Routledge International Handbook on Hate Crime, Routledge, London, 370.

4. Iganski, P., Levin, J. (2015): Hate Crime: A Global Perspective, Routledge, New York, 49.

5. Jenness, V., Broad, K. (2009): Hate Crimes: New Social Movements and the Politics of Violence, Aldine Transaction, New Jersey, 144.

6. Krohn, M., Lizotte, A., Hall, G. P. (2009): Handbook on Crime and Deviance, Springer, London, 539.

7. Kurtz, L. (1999): Encyclopedia of Violence, Peace, and Conflict, Three-Volume Set, Academic Press, San Diego, 94.

8. Lau Chin, J. (2004): The Psychology of Prejudice and Discrimination: Bias based on gender and sexual orientation, Praeger, London, 163.

9. Lebrun, M. (2012): Rebels in Society: The Perils of Adolescence, Rowman \& Littlefield Publishers, Lanham, 122.

10. Levin, J., McDevitt, J. (2002): Hate crimes revisited: America's war against those who are different, Basic book, New York, 80.

11. Miladinović, J. (2015): Procesuiranje zločina izmržnje: mržnjaka o obavezna otežavajuća okolnost, Biltensudske prakse, Niš, 37.

12. Mizrahi, T., Davis, L. (2008): The Encyclopedia of Social Work: 4 Volume Set, Oxford University Press, Oxford, 315.

13. Momen, R. (2008): Empirical Study of Hate Crimes in the United States: A Systematic Test of Levin and McDevitt's Typology of Offenders, ProQuest, Morgantown, 9.

14. Perry, B. (2003): Hate and Bias Crime: A Reader, Routledge, New York, 29.

15. Perry, B. (2009): Hate Crimes, Greenwood Publishing Group, London, 119.

16. Phillips, C., Webster, C. (2013): New Directions in Race, Ethnicity and Crime, Routledge, London, 30.

17. Retrieved 21 March 2016 from: http://psc.dss.ucdavis.edu/rainbow/HTML/ prej_func.html

18. Retrieved 4 March 2016 from http://prospect.org/article/daily-meme-brief- 
history-hate-crime

19. Roulstone, A., Mason-Bish, H. (2013): Disability, Hate Crime and Violence, Routledge, London, 101.

20. Turpin-Petrosino, C. (2015): Understanding Hate Crimes: Acts, Motives, Offenders, Victims, and Justice, Routledge, London, 7.

21. Law on Prevention of Violence and Misconduct at Sports Events, „Official Gazette RS“, br. 67/2003, 101/2005, 90/2007, 72/2009, 111/2009 and 104/2013;

22. Law on Prohibition of Discrimination, „Official Gazette RS“, No. 22/2009; 